CZASOPISMO INŻYNIERII LĄDOWEJ, ŚRODOWISKA I ARCHITEKTURY JOURNAL OF CIVIL ENGINEERING, ENVIRONMENT AND ARCHITECTURE

JCEEA, t. XXXIV, z. 64 (2/II/17), kwiecień-czerwiec 2017, s. 161-172, DOI: 10.7862/rb.2017.89

\author{
Marek GOSZTYŁA ${ }^{1}$ \\ Stanisław LEŚ ${ }^{2}$ \\ Krystian SIKORSKI ${ }^{3}$
}

\title{
PRELIMINARIA NAD STANEM BADAŃ PRAKTYKI KONSERWATORSKIEJ W RZESZOWIE
}

\begin{abstract}
W niniejszym artykule poruszono problematykę konserwacji obiektów zabytkowych $\mathrm{w}$ zakresie przeciwdziałania negatywnym skutkom transportu wody wewnątrz muru. Często spotykanym zjawiskiem jest niszczenie przegród zewnętrznych w strefie przyziemnej oraz w wyższych partiach. Najpowszechniejszą przyczyną degradacji są nieprawidłowe rozwiązania w zakresie odtworzenia izolacji pionowej i poziomej muru oraz wykonania wadliwych tynków renowacyjnych, pomalowanych farbami o niskiej dyfuzji wody. W związku z tym zwrócono uwagę na przyjęte rozwiązania systemowe, a także na metodykę wykonania prac związanych z konserwacją. Pierwszym obiektem, którego stan istniejący został przebadany jest Klasztor O.O. Bernardynów w Rzeszowie. Obiekt mimo niedawnych (okres 10 lat) prac związanych z odtworzeniem izolacji oraz tynków renowacyjnych wykazuje duży stopień degradacji spowodowanej transportem wody wewnątrz struktury muru. Kolejnym obiektem referencyjnym jest Kościół WNMP na osiedlu Zalesie w Rzeszowie. Ocena stanu istniejącego poddała pod wątpliwość istnienie oraz jakość wykonanej izolacji przegród. Jako ostatnia zestawiona została kamienica $\mathrm{nr} 2$ zlokalizowana przy ul. płk. Leopolda Lisa-Kuli w Rzeszowie. Istniejący stan kamienicy podobnie jak w przypadku poprzednich obiektów wskazuje na wadliwe rozwiązania systemowe. Mając na względzie fakt, iż wskazane obiekty są jedynie odsetkiem wyłonionym $\mathrm{z}$ większego spektrum zastanowić należy się nad myślą z preambuły Karty Krakowskiej 2000, przypominającej o obowiązku pielęgnacji dziedzictwa kulturowego. Przykrym jest zjawisko polegające na złudnej redukcji kosztów związanych z naprawą starego budownictwa. Dodatkowo należy podkreślić, iż rażące braki w dokumentacji dotyczą nawet obiektów o wysokiej wartości architektoniczno-kulturowej.
\end{abstract}

Słowa kluczowe: woda w obiekcie, izolacja pionowa, izolacja pozioma, tynk renowacyjny

\footnotetext{
${ }^{1}$ Autor do korespondencji / corresponding author: Marek Gosztyła, Politechnika Rzeszowska, Katedra Konserwacji Zabytków, ul. Powstańców Warszawy 12, 35-959 Rzeszów, gosztyla@prz.edu.pl

${ }^{2}$ Stanisław Leś, Technolog PCI, stanisław.les01@ gmail.com

${ }^{3}$ Krystian Sikorski, doktorant WBIŚiA PRz, mr.krystian.sikorski@gmail.com
} 


\section{Wstęp}

Zagadnienie konserwacji obiektów zabytkowych jest tematem rozwojowym (ze względu na nieustający rozwój technologii), a zarazem obarczonym dużym stopniem trudności gdyż ingerencja w obiekt związana jest $\mathrm{z}$ ryzykiem utraty jego walorów architektonicznych lub dalszymi procesami degradacji.

Omawiając problematykę konserwatorską warto zwrócić uwagę, iż spora część publikacji uwzględnia historię obiektów i teorię konserwatorską związaną $\mathrm{z}$ ich ochroną. Mniejszą uwagę przywiązuje się do praktycznej strony zagadnienia. Nierzadko przytaczana metodyka wykonania robót jest ogólnikowa (bez dokładniejszego ich opisania). Tendencję taką, zauważyć można, również w ekspertyzach wykonywanych przez osoby posiadające konkretne kompetencje.

Analizując proces konserwacji zabytków, podzielić możemy go na cztery podstawowe etapy: przedprojektowy (inwentaryzacja i ocena stanu technicznego obiektu wraz z szerokim spektrum badawczym), projektowy (zaproponowanie sposobów naprawy przy użyciu określonych materiałów), wykonawstwa (przeprowadzenie przewidywanych robót) oraz eksploatacji.

Na każdym z poszczególnych etapów dojść może do popełnienia błędów, które zaburzą prawidłowe działanie mechanizmu.

W tym miejscu zwrócić uwagę należy na myśl wynikającą z preambuły Karty Krakowskiej 2000, która przypomina, iż wraz ze zmianą ustroju zaszło zjawisko demokratyzacji zabytków i to na naszych barkach spoczywa obowiązek prawidłowego zarządzania własnym dziedzictwem [5].

\section{Wybór obiektów referencyjnych}

Chcąc dokładnie przyjrzeć się zagadnieniu praktyki konserwatorskiej, przeanalizowano obiekty usytuowane w Rzeszowie. Jako pierwszy spośród nich wybrano jeden ze znaczących, jakim, bez wątpienia, jest Klasztor O.O. Bernardynów. Sprzyjającym jest fakt, iż obiekt ten w ostatnich latach przechodził szereg prac konserwatorskich. Kolejno uwagę poświęcono Kościołowi Wniebowzięcia Najświętszej Maryi Panny oraz kamienicy nr 2 przy ulicy płk. Leopolda Lisa-Kuli.

Ze względu na przyjęty zakres zagadnienia w artykule skupiono się na sposobach zabezpieczania murów przed szkodliwym oddziaływaniem wód.

\section{Woda w obiekcie}

Przy niewłaściwej eksploatacji bądź wadliwie wykonanym zabezpieczeniu lub, w przypadku obiektów zabytkowych, jego braku (pamiętać należy iż w przypadku obiektów datowanych na pół wieku i starszych, które nie były poddane procesom konserwacji mamy 99\% pewności, iż izolacja przeciwwilgociowa nie spełnia wymaganych założeń) woda wnika w głąb struktury materiałów, 
z których wykonano poszczególne elementy budynku. Bezpośrednim tego efektem jest zwiększenie wilgotności przegród, któremu towarzyszy proces ich zasalania przez sole mineralne. Do najpowszechniej spotykanych rodzajów soli zaliczamy siarczany, chlorki, azotany oraz węglany [2]. Prawidłowe rozpoznanie soli znajdujących się $\mathrm{w}$ elemencie pozwala na sprecyzowanie przyczyny powstawania mechanizmu zawilgocenia. Praktyka wskazuje, iż największe stężenie chlorków bądź azotanów stwierdzić można przy zawilgoceniu pochodzącym z gruntu, natomiast wysoka zawartość siarczanów wskazuje na kwaśne deszcze [3]. Osobnymi przypadkami są: zjawisko zasolenia pierwotnego, które w odniesieniu do obiektów zabytkowych będzie mniej prawdopodobne (ewentualne zasolenie przez stosowanie impregnatów do elementów organicznych) oraz zjawisko uaktywniania soli spowodowane wilgotnością higroskopijną (zła eksploatacja obiektu). Konsekwencją występowania poszczególnych zjawisk lub (co jest bardziej prawdopodobne) ich skumulowania jest obniżenie walorów estetycznych i właściwości wytrzymałościowych elementów wchodzących w skład budynku, co bezpośrednio przekłada się na stateczność całej konstrukcji. Kolejnym niekorzystnym efektem zawilgocenia muru jest wzrost kosztów eksploatacji związany z utrzymaniem ciepła. Przyczyną niekorzystnego stanu jest wzrost przewodnictwa cieplnego mokrej przegrody. Doskonałym przykładem jest cegła ceramiczna, której współczynnik przewodzenia ciepła w warunkach średnio wilgotnych równy jest $\lambda=0,77 \mathrm{~W} / \mathrm{m} \cdot \mathrm{K}$, natomiast $\mathrm{w}$ sytuacji $15 \%$ zawilgocenia (zgodnie $\mathrm{z}$ normami $\mathrm{w}$ przypadku zawilgocenia $>12 \%$ klasyfikowany jako mur mokry) oscyluje $\mathrm{w}$ granicach $\lambda=1,6 \mathrm{~W} / \mathrm{m} \cdot \mathrm{K}$ [4] (pamiętać należy, iż bez rozwiązania problemu zawilgocenia nie ma możliwości poprawy sytuacji termicznej, termomodernizacje w danej sytuacji są bezskuteczne). Dodatkowym zagrożeniem wynikającym z nadmiernej ilości wody w elemencie jest możliwość występowania drobnoustrojów w postaci grzybów oraz występowaniem owadów, które pogarszają lub uniemożliwiają dalsze użytkowanie obiektu, a także narażają elementy organiczne konstrukcji na degradację.

\section{Klasztor O.O. Bernardynów}

\subsection{Powstanie klasztoru}

Świątynię OO. Bernardynów wybudowano w I połowie XVII w., Zlokalizowana została w miejscu, w którym uprzednio stał drewniany kościółek powołania Wniebowzięcia Panny Marii wybudowany w celu uczczenia objawienia się Matki Bożej z 1513 roku. Murowany kościół zawdzięcza swe istnienie ówczesnemu właścicielowi miasta Mikołajowi Spytko Ligęzie. Budowa rozpoczęta w 1624 roku, przez budowniczych z Lipska, trwała 5 lat do roku 1629 kiedy to Ligęza przekazał ją Bernardynom [6]. 


\subsection{Praktyki konserwatorskie przed rokiem 2001}

W pierwszych latach funkcjonowania świątyni wykonano polichromię, a na przełomie XIX i XX wieku gruntownie ją odnowiono. Prace restauracyjne wykonano pod nadzorem Zygmunta Hendla, który zaproponował projekt wyposażenia kościoła oraz jego możliwego przekształcenia [1]. Realizacji doczekały się jedynie założenia związane m.in. z przebudową Ołtarza Głównego czy kryptą grobową rodziny Ligęzów.

W roku 1906 inż. Janusz Rawicz Niedziałkowski określa zakres prac, które mają na celu obniżenie zawilgocenia murów klasztoru. Dodatkowo Niedziałkowski w swym opracowaniu określa stan budynku klasztornego jako fatalny, na co wpływ mają takie rzeczy jak przegniłe fundamenty oraz odpadające tynki.

Ponad pół wieku po gruntownej restauracji (1957-59) wykonanej wg. planów Hendla i Niedziałkowskiego wnętrze zespołu klasztornego zostało poddane restauracji. Prace polegały na konserwacji polichromii, prezbiterium oraz transeptu [1].

W tym też okresie dokonano przeglądu technicznego stwierdzającego zawilgocenie murów oraz konieczność częściowej wymiany więźby dachowej.

Lata 70 zapisały się w historii obiektu dużymi literami, gdyż właśnie wtedy dokonano dokładnej oceny stanu technicznego zarówno wyposażenia jak i konstrukcji klasztoru. Podkreślić należy, iż zabiegi te miały charakter mocno ingerujący w strukturę obiektu co, uznać można za odstępstwo od fundamentalnej zasady nieingerowania $w$ obiekt zabytkowy.

\subsection{Prace konserwatorskie - Etap przedprojektowy}

Etap przedprojektowy obejmuje wszystkie działania mające na celu zdiagnozowanie przyczyn występujących uszkodzeń, począwszy od opisu opiniowanej zabudowy, poprzez pobranie próbek wraz z wykonaniem badań, a kończąc na sformułowaniu wniosków. W przypadku klasztoru O.O. Bernardynów badania mechanizmów zagrożenia murów zostały wykonane przez zespół (któremu przewodniczył dr inż. St. Karczmarczyk) [7]. W ramach niniejszego referatu (w zgodzie z jego tematyką) posłużono się wybranymi wynikami badań przeprowadzonych przez w/w zespół. Ściana zachodnia wieży wykazywała wysoki poziom zawilgocenia, osiągający wysokość do $230 \mathrm{~cm}$ ponad poziom terenu, natomiast na ścianie zachodniej transeptu poziom zawilgocenia osiągał wysokość $180 \mathrm{~cm}$ od poziomu terenu. Otrzymane wyniki, uwzględniając formy i skalę zagrożenia murów, wskazywały jednoznacznie na potrzebę niezwłocznego wykonania prac naprawczych, w których skład wchodzić powinno wykonanie izolacji poziomej ścian oraz tynków szerokoporowych (renowacyjnych) [7]. 


\subsection{Stan istniejący}

O prawidłowości wykonania prac konserwatorskich świadczy szereg czynników. O ile poprawa walorów użytkowych, dostrzegalna przez osoby przebywające stale lub czasowo w obiekcie jest pojęciem subiektywnym, zależnym od odbioru jednostek o tyle stan techniczny, związany z ewentualnym pogorszeniem estetyki, jest widoczny. Niezadowalający stan obiektów, pomimo uprzedniej naprawy, jest reakcją obiektu na zastosowanie wadliwych rozwiązań technologicznych.

Sytuacja, w której obecnie znajduje się kościół O.O. Bernardynów zdaje się być doskonałym na to przykładem. Pomimo wykonania szeregu prac mających na celu zabezpieczenie obiektu, sytuacja degradacji nie została powstrzymana. W październiku 2016 roku dokonano oględzin oraz wykonano badania stopnia zawilgocenia na podstawie, których stwierdzono szereg nieprawidłowości.

Pierwszym objawem niepożądanych reakcji, który przyciąga uwagę, jest znaczne pogorszenie walorów estetycznych obiektu. Biorąc jako przykład zachodnią ścianę wieży kościelnej, stan obecny nie różni się znacząco od stanu $\mathrm{z}$ roku 2001. Na elewacji widoczne są liczne przebarwienia, które próbowano maskować poprzez zamalowanie farbą. W przypadku stosowania farb o słabej dyfuzyjności takie postępowanie doprowadzi do dalszego pogorszenia stanu istniejącego, które objawiać będzie się poprzez łuszczenie farb i odspajanie tynków. Celem potwierdzenia złego stanu przegrody dokonano sprawdzenia zawilgocenia muru do wysokości ok. $150 \mathrm{~cm}$. Pomiary wykazały zawilgocenie na poziomie $20 \%$ (zgodnie z obowiązującymi standardami mur o wilgotności powyżej $12 \%$ jest uznawany jako mokry). Taki stan rzeczy wskazuje jednoznacznie na zjawisko podciągania kapilarnego (podobnie jak w przypadku badań z roku 2001), które świadczy o wadliwie wykonanej izolacji poziomej przegrody (błędy wykonawcze lub błędne rozwiązania materiałowe).

Kolejnym punktem było zwrócenie uwagi na stan cokołu wykonanego z piaskowca. Doskonale widocznym jest zaplamienie sięgające $1 / 4$ wysokości, które spowodowane zostało najprawdopodobniej poprzez oddziaływanie wód rozbryzgowych. Przyczyną takiego stanu rzeczy jest brak odpowiedniej impregnacji kamienia lub nieprzestrzeganie okresów kontrolnych. Warto pamiętać, że w przypadku zastosowania materiału hydrofobowego woda nie ma możliwości wniknięcia w głąb struktury zabezpieczonego materiału.

Zaistniała sytuacja ma miejsce na wszystkich sprawdzanych elewacjach kościoła, $\mathrm{tj} .:$ wschodniej, południowej i zachodniej. Na fotografiach $\mathrm{nr} 2 \mathrm{a}$ i $2 \mathrm{~b}$ oraz zobrazowano stan istniejący. Na murach widoczne jest odchodzenie płatów farby, która - podobnie jak w przypadku wieży - jest efektem powtórnego nakładania kolejnych warstw. Badania poziomu zawilgocenia w tych miejscach również wskazywały na wadliwą izolację poziomą (zawilgocenie na poziomie 15\%). Na fotografii $\mathrm{nr} 1$ uwidoczniono szkodliwe działanie wód rozbryzgowych, które nadają cokołowi charakterystyczny zielony kolor. Brak odbarwień w rejonach rur spustowych świadczy o poprawnie wykonanej naprawie instalacji (rys. 2b). 


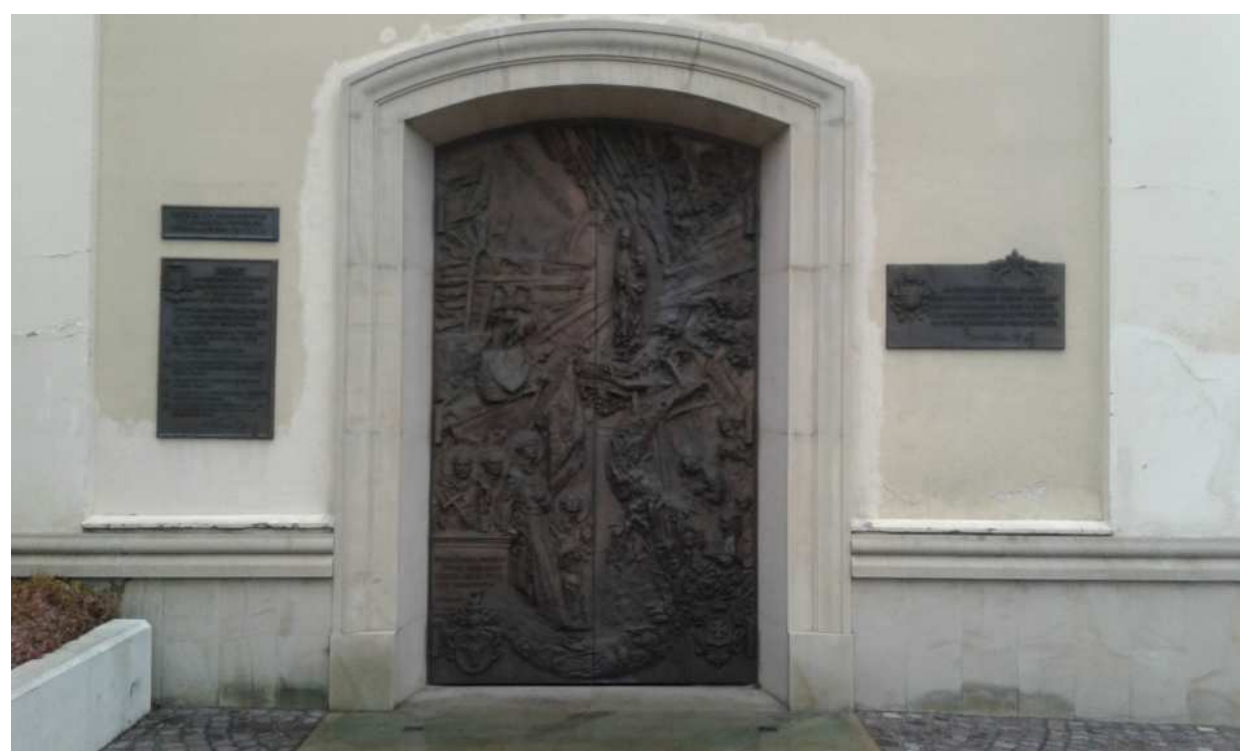

Rys. 1. Zachodnia elewacja wieży, fot. autor, październik 2016

Fig. 1. West elevation of tower, fot. author, October 2016
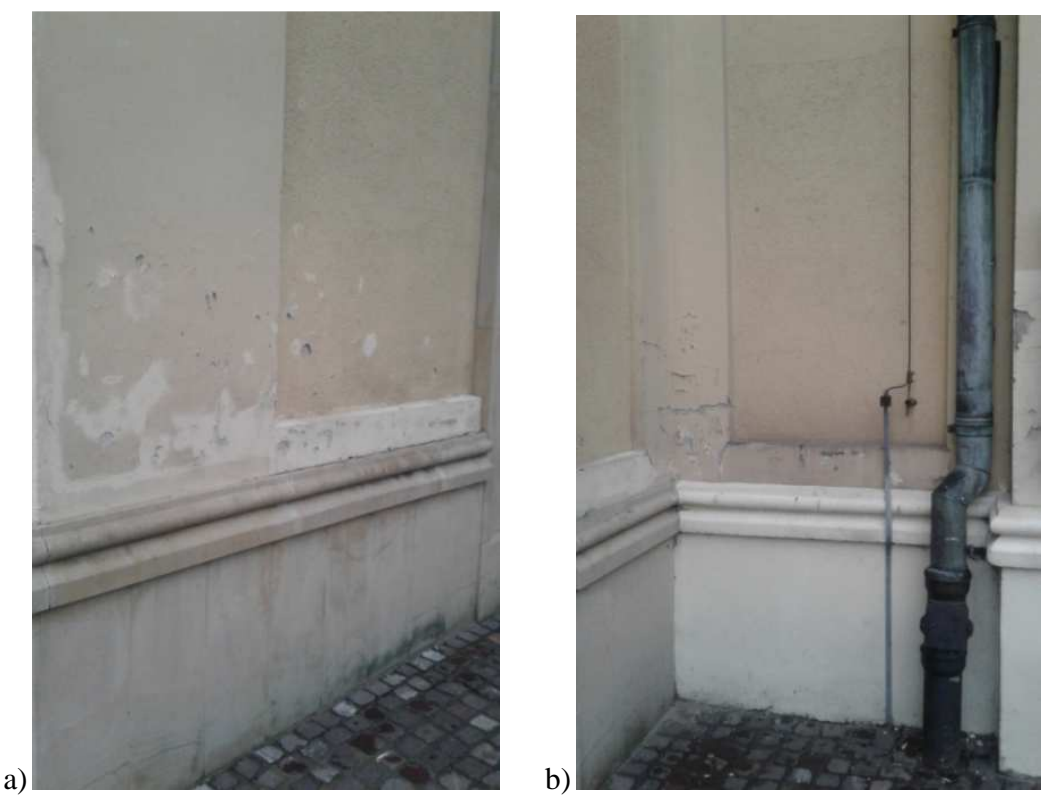

Rys. 2. Degradacja elewacji, fot. autor, październik 2016

Fig. 2. Degradation of elevation, fot. author, October 2016 
Widoczne na zdjęciach odspajanie farby oraz częściowe odspajanie tynków świadczy o destrukcyjnym działaniu soli budowlanych. W przypadku dużego zwilgocenia muru oraz występowania zasolenia powinna być przeprowadzona renowacja murów w sposób bardzo szczegółowy. W miejscu odspojenia tynków na elewacji południowo-wschodniej widoczny jest brak kompletnego sytemu wykonania tynków renowacyjnych, stwierdzono częściowe zastosowanie tynków wapienno-cementowych. Uwaga ta zawarta została również we wnioskach opracowania wykonanego przez Politechnikę Krakowską. Zauważyć można pocienienie tynków (wierzchni tynk powinien mieć grubość minimum $2 \mathrm{~cm}$, natomiast widoczny na fotografii $3 \mathrm{ma}$ ok. $0,5 \mathrm{~cm}$ ) oraz brak zastosowania tynków podkładowych (o grubości minimum $1 \mathrm{~cm}$ ). Skutkiem pocienienia tynku jest brak skutecznej krystalizacji soli budowlanej w strukturach tynku renowacyjnego. Sole wraz z wilgocią z łatwością przedostają się do wierzchniej warstwy, niszcząc farbę i powodując odspajanie tynku.

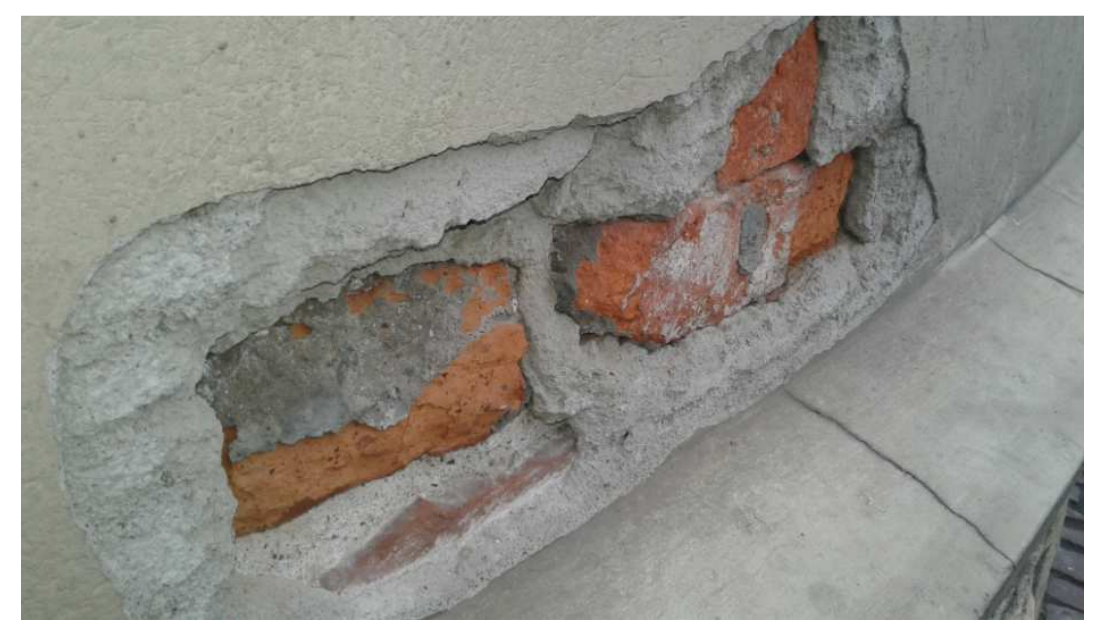

Rys. 3. Odspojenie tynku, fot. autor, październik 2016

Fig. 3. Disconnection of plaster, fot author, October 2016

Na cokole kamiennym (część południowo-wschodnia) - rys. 4, występuje wysokie zawilgocenie oraz częściowe odspajanie kamienia na skutek braku impregnacji. Rzeczą wartą podkreślenia jest niewłaściwe ukierunkowanie spadków gzymsu nad cokołem (niewystarczające pochylenie), które doprowadzić może do zastoin wilgoci (deszcz, śnieg), a w konsekwencji do przyspieszenia procesów destrukcji materiału.

\subsection{Wnioski}

Rozpatrując istniejący stan rzeczy należałoby wykonać powtórną renowację obiektu, zgonie ze sztuką budowlaną i zastosowaniem materiałów posiadających 


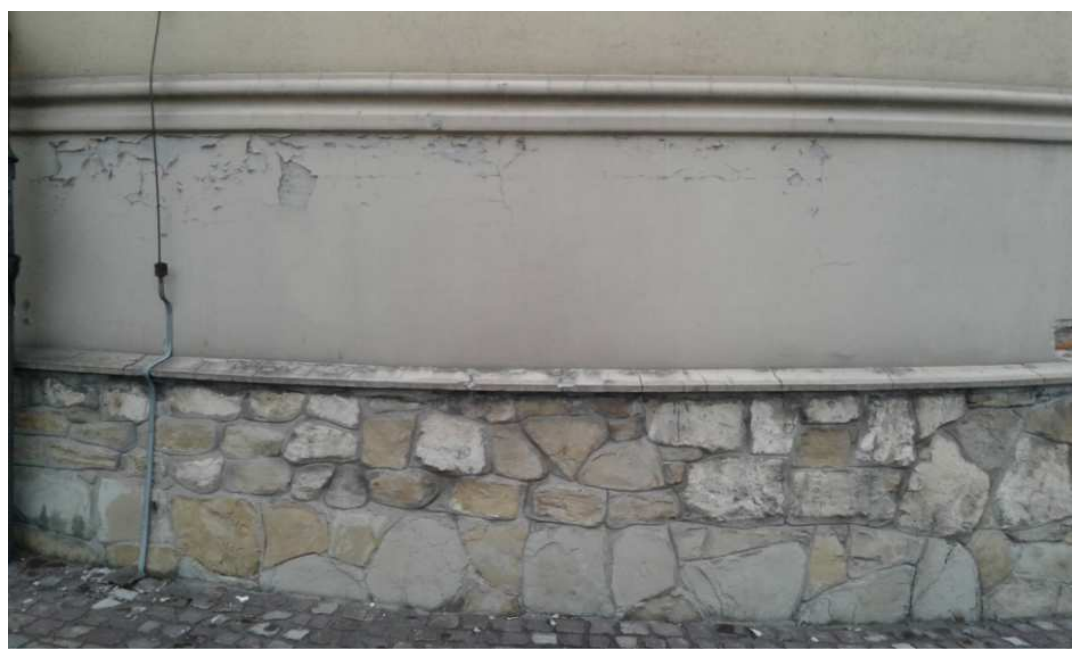

Rys. 4. Cokół kamienny, fot. autor, październik 2016

Fig. 4. Stone plinth, fot. author, October 2016

atesty (aprobatę organizacji Naukowo-Technicznej Grupy Roboczej ds. Utrzymania Budowli i Ochrony Zabytków (WTA)). Należy dokładnie określić poziom zawilgocenia murów, stopień zasolenia i wykonać opracowanie dokumentacji ponownej renowacji obiektu.

\section{Kościół Najświętszej Maryi Panny}

\subsection{Powstanie kościoła}

W XV w. dziedzic Stanisław Pilecki osadził w Zalesiu i okolicach Rusinów z prawosławnym popem. Następnie w wyniku Unii Brzeskiej parafia prawosławna ustanowiona została parafią greckokatolicką pod wezwaniem Wniebowzięcia NMP. W XX w., Kuria Biskupia w Przemyślu zmieniła opuszczoną po wojnie cerkiew w kościół filialny [10].

\subsection{Praktyki konserwatorskie}

Przeprowadzone kwerendy archiwalne potwierdzają wykonanie prac związanych ze zmianą wyposażenia wnętrza (1982 rok) oraz prac naprawczych polegających na naprawie tynków zewnętrznych (1991 rok). W latach 2000 do 2002 wykonano prace związane ze zmianą bryły kościoła (dobudowa zachrystii, kruchty oraz nadbudowa części bocznych). W roku 2016 wykonano prace mające na celu osuszenie murów kościoła. Polegały one na skuciu zasolonych i zawilgoconych tynków zewnętrznych, w miejsce których wykonano nowe tynki renowacyjne. $Z$ cokołu kamiennego okalającego kościół skuto tynki cementowe celem jego osuszenia. 


\subsection{Stan istniejący}

Po roku 1991 wymieniono tynki zewnętrzne, co jak widać na fotografii $\mathrm{nr} 5$, nie zapobiegło dalszej degradacji obiektu $[9,10]$. Taką sytuację tłumaczyć należy brakiem skutecznych izolacji poziomych i pionowych murów kościelnych.

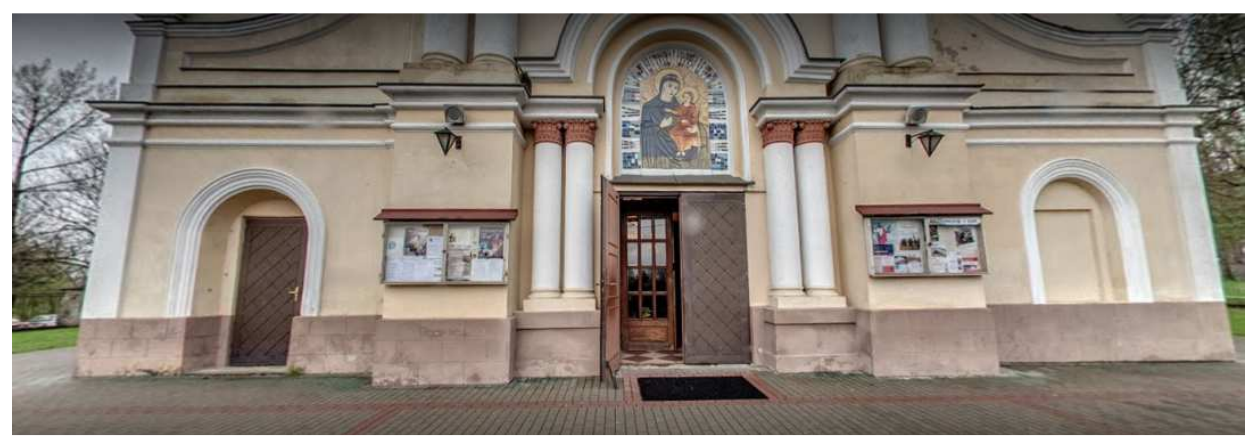

Rys. 5. Elewacja frontowa, fot. Google Mapy, kwiecień 2016

Fig. 5. Front elevation, fot. Google Maps, April 2016

W grudniu 2016 roku wykonano badania stanu zawilgocenia (rys. 6) przegród zewnętrznych. Średni poziom zawilgocenia strefy cokołowej przekraczał wartość $10 \%$. Stan taki kwalifikuje mur jako bardzo zawilgocony. Wartym podkreślenia jest fakt, iż skucie tynku nie doprowadzi do osuszenia murów.

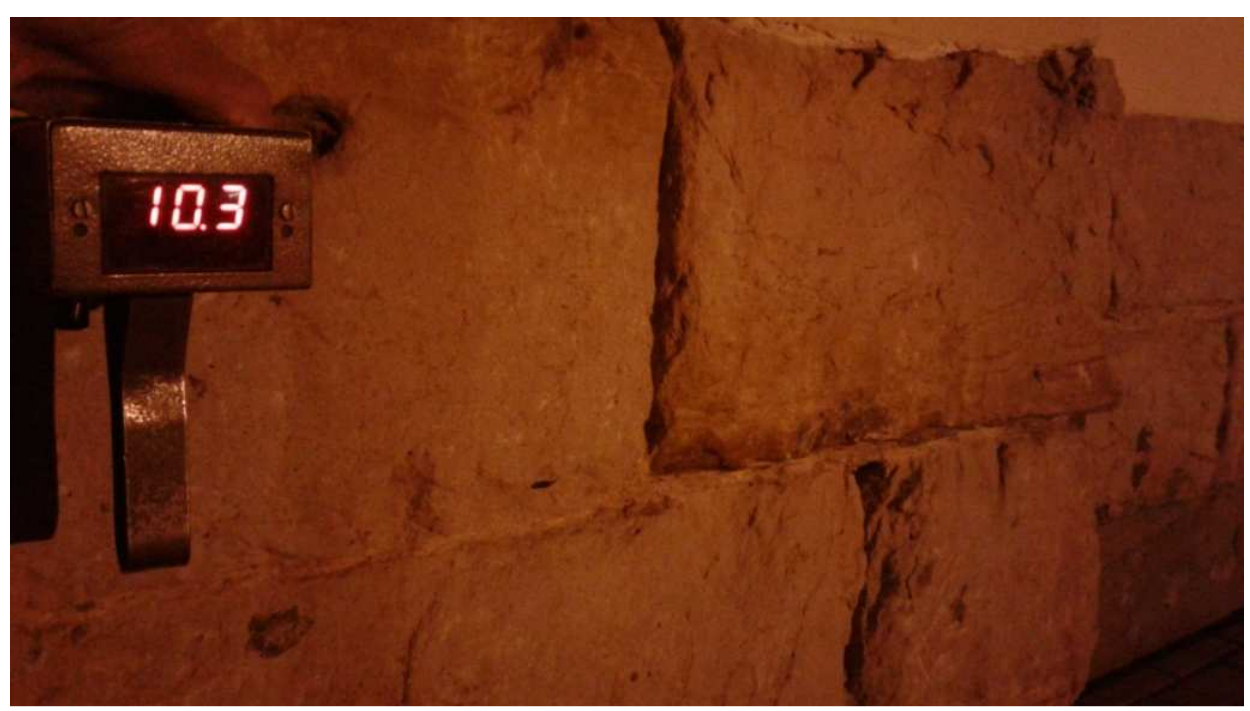

Rys. 6. Cokół kamienny, fot. autor, grudzień 2016

Fig. 6. Stone plith, fot. author, December 2016 


\subsection{Wnioski}

Brak wykonania należytych izolacji pionowych i poziomych doprowadzi do dalszej degradacji murów kościoła.

Zaleca się wykonanie izolacji pionowej zewnętrznej ścian fundamentowych celem powstrzymania naporu wód gruntowych. Dodatkowo wykonać należy izolację poziomą zewnętrznych ścian fundamentowych celem zlikwidowania podciągania kapilarnego. Na cokole kamiennym wykonać należy tynki renowacyjne. Zabieg ten spowoduje osuszenie cokołu i akumulację soli budowlanych.

\section{Kamienica nr 2 przy ulicy płk. Leopolda Lisa-Kuli}

\subsection{Powstanie obiektu}

Kamienica wybudowano w drugiej połowie XIX wieku. Budynek posiada 3 kondygnacje nadziemne oraz 1 podziemną. Obiekt zarządzany jest przez osobę prywatną [8].

\subsection{Prace konserwatorskie - Etap wykonawczy}

W skutek przeprowadzonej kwerendy archiwalnej zebrano znikomą dokumentację, na podstawie której określić można sposób wykonania przepony poziomej.

$\mathrm{Z}$ fotografii nr 7 wynika, iż iniekcja krystaliczna wykonana została niezgodnie ze sztuką budowlaną. Wskazuje na to brak wypełnienia otworów oraz zastosowanie materiałów niewiadomego pochodzenia. Wartym podkreślenia jest

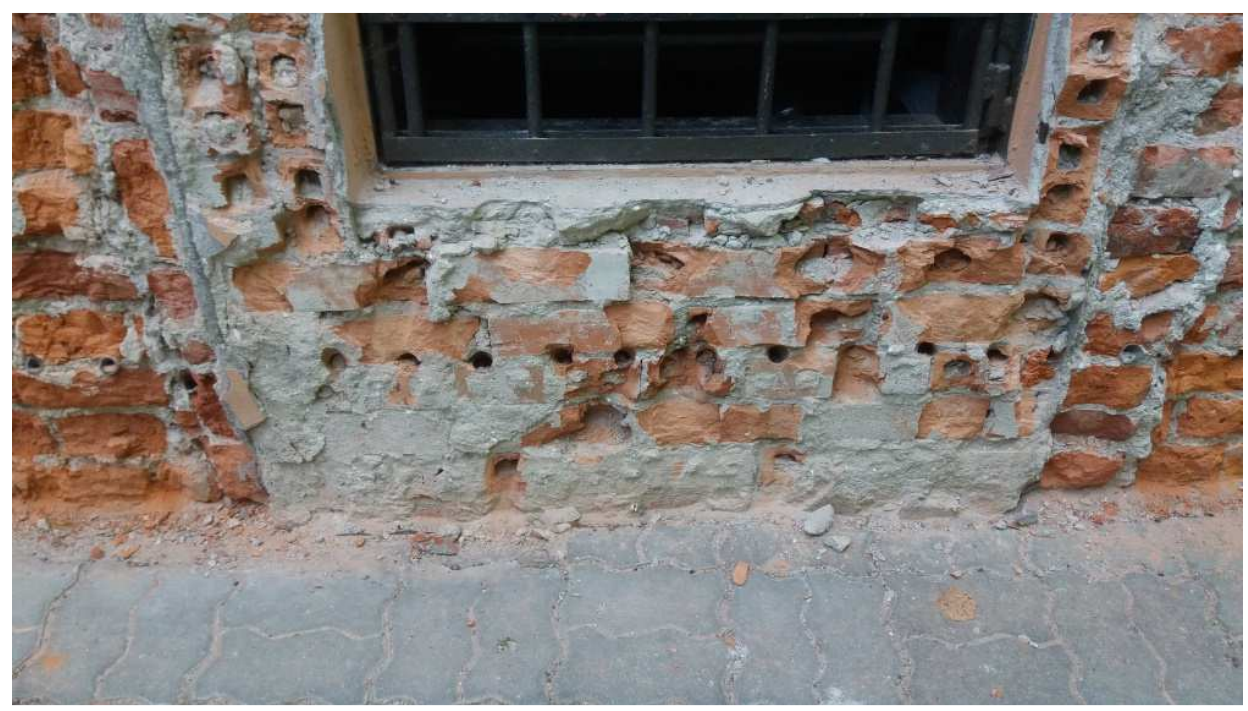

Rys. 7. Iniekcja, fot. autor, 2015

Fig. 7. Injection, fot. author, 2015 
fakt, iż iniekcja została wykonana w cegle dziurawce co, ze względu na strukturę materiału, jest niezgodne $\mathrm{z}$ technologią, ponieważ injekt nie ma możliwości szczelnego wypełnienia przestrzeni wewnątrz muru.

\subsection{Stan istniejący}

W roku 2016 wykonano badania wilgotności murów (rys. 8), które wykazały zawilgocenie na poziomi ok. $20 \%$ co kwalifikuje mur jako mokry. Wykonana przepona pozioma, metodą iniekcji krystalicznej nie spełnia przewidywanych kryteriów, czego efektem jest odspajanie tynków spowodowane przez wysokie zawilgocenie murów oraz zasolenie murów. Tynk pokryty jest farbami akrylowymi, charakteryzującymi się brakiem dyfuzji, co jak widać na poniższym zdjęciu powoduje jej odspajanie.

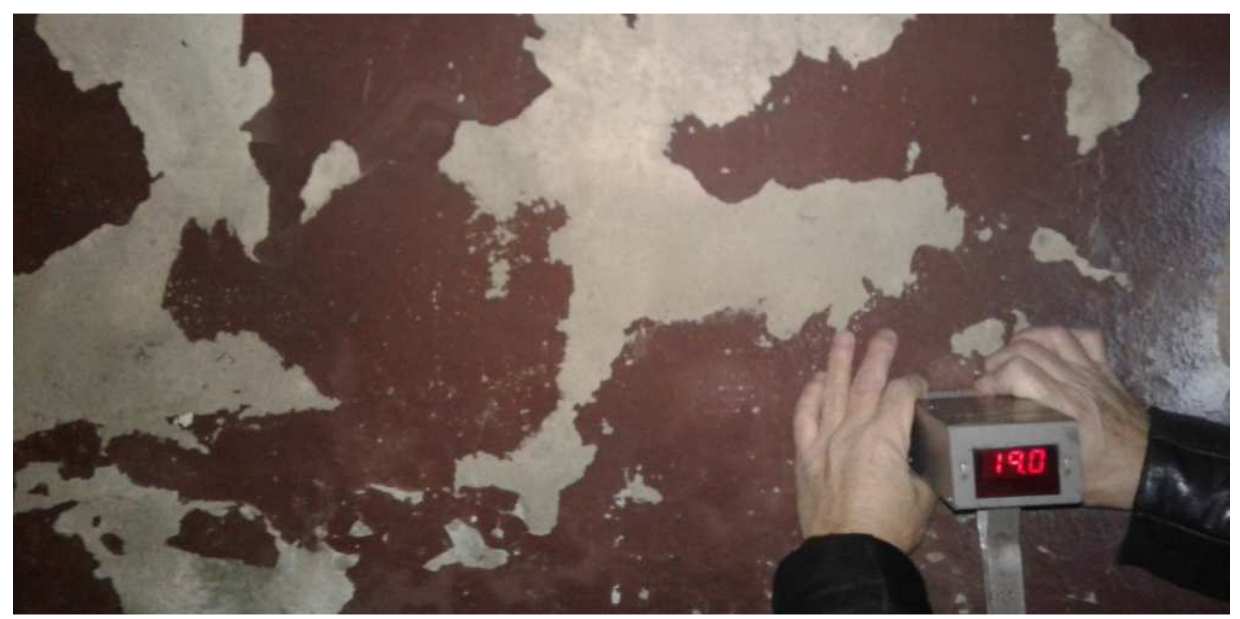

Rys. 8. Tynk pokryty farbą akrylową, fot. autor, grudzień 2016

Fig. 8. Plaster covered with acrylic paint, fot. author, December 2016

\subsection{Wnioski}

Planując kolejny remont należy uwzględnić ponowne wykonanie przepony poziomej ścian, skuć zasolone i zawilgocone tynki do wysokości $80 \mathrm{~cm}$ poza poziom zniszczeń (wykonać je jako tynki renowacyjne). W przypadku malowania wykonać wyłącznie farbami krzemianowymi.

\section{Podsumowanie}

Analizując omówione przypadki oczywistym jest fakt, iż podstawowym zagadnieniem związanym z konserwacją obiektu zabytkowego powinno być zabezpieczenie przed oddziaływaniem wody i soli budowlanych. Jest to niemożliwe, jeśli nie zostanie przecięta więź przyczynowo - skutkowa. W tym celu nale- 
ży wykonać izolacje wtórne ścian, które odetną dalszy dopływ wody do przegrody. Oczywistym jest zastosowanie tynków renowacyjnych, których zadaniem jest osuszenie muru (iniekcje należy wykonać jedynie atestowanym środkiem). W tym miejscu należy ponownie powołać się na Kartę Krakowską 2000, która uświadamia, iż za zaniedbanie płaci się podwójną cenę. Pierwszym wymiarem jest utrata dziedzictwa kulturowego, drugim ponoszenie kosztów kolejnych napraw cyklicznie pojawiających się uszkodzeń.

\section{Literatura}

[1] M. Gosztyła, B. Jagiełła, Konserwacja zabytków architektury, Rzeszów 2015.

[2] M. Rogalska, Sole budowlane, Konferencja Naukowa, Lublin 2007.

[3] M. Rokiel, Hydroizolacje w budownictwie, Warszawa 2006.

[4] M. Trochonowicz, Wilgoć w obiektach budowlanych, Konferencja Naukowa, Lublin 2007.

[5] Karta Krakowska 2000, Kraków 2002.

[6] Kroniki O.O. Bernardynów, Kraków.

[7] St. Karczmarczyk, B. Ciepiela-Biernat, M. Mazur, Badania mechanizmów zagrożenia murów klasztoru i kościoła O.O. Bernardynów w Rzeszowie przez wilgoć i sole rozpuszczalne, Kraków 2001.

[8] MZBiM.

[9] www.google.maps.pl (dostęp: 15.12.2016 r.).

[10] www.wnmp.rzeszow.pl (dostęp: 15.12.2016 r.).

\section{PRELIMINARIES ABOVE THE STATE OF CONSERVATION PRACTISE IN RZESZOW}

\section{S u m m a r y}

The article brings up the problems of the preservation of antique objects in the range of counteraction of the negative results of the transport of water within the wall. Often met occurrence is a destruction of outer wall in ground zone and in the higher parties. The most common reason of degradation are wrong solutions in the range of the reconstruction of perpendicular and horizontal wall insulation. Moreover degradation of wall may be caused by wrong plaster and acrylic paint. All of that brought attention on the systemic sollutions and on methodology of old buildings preservation. The first object, which existing state was examined is monastery Of O.O. Bernardynow in Rzeszow. A WNMP Church is next referential object, placed in Rzeszów. The evaluation of existing state shoved lacks of insulation and the low quality of product used in proces or conservation. Last of all the old building located by the street of płk. Leopold Lisa-Kuli was examined. The existing state of the tenement is pointing at wrong system solutions. Taking into consideration fact that shown objects are only an appointed percentage from the greater spectrum it is necessary to puzzle above the thought from the preamble Cracovia Card 2000. The idea of CC2000 is to remind that the care over the cultural legacy is society's duty. Sad thing is the fact of cuting down the cost connected with old buildings conservation. Additionally one should emphasize that striking gaps in documentation concern even objects with the architectural and cultural value.

Keywords: wather in the wall, vertical isolation, horisontal isolation, renovation plaster 